
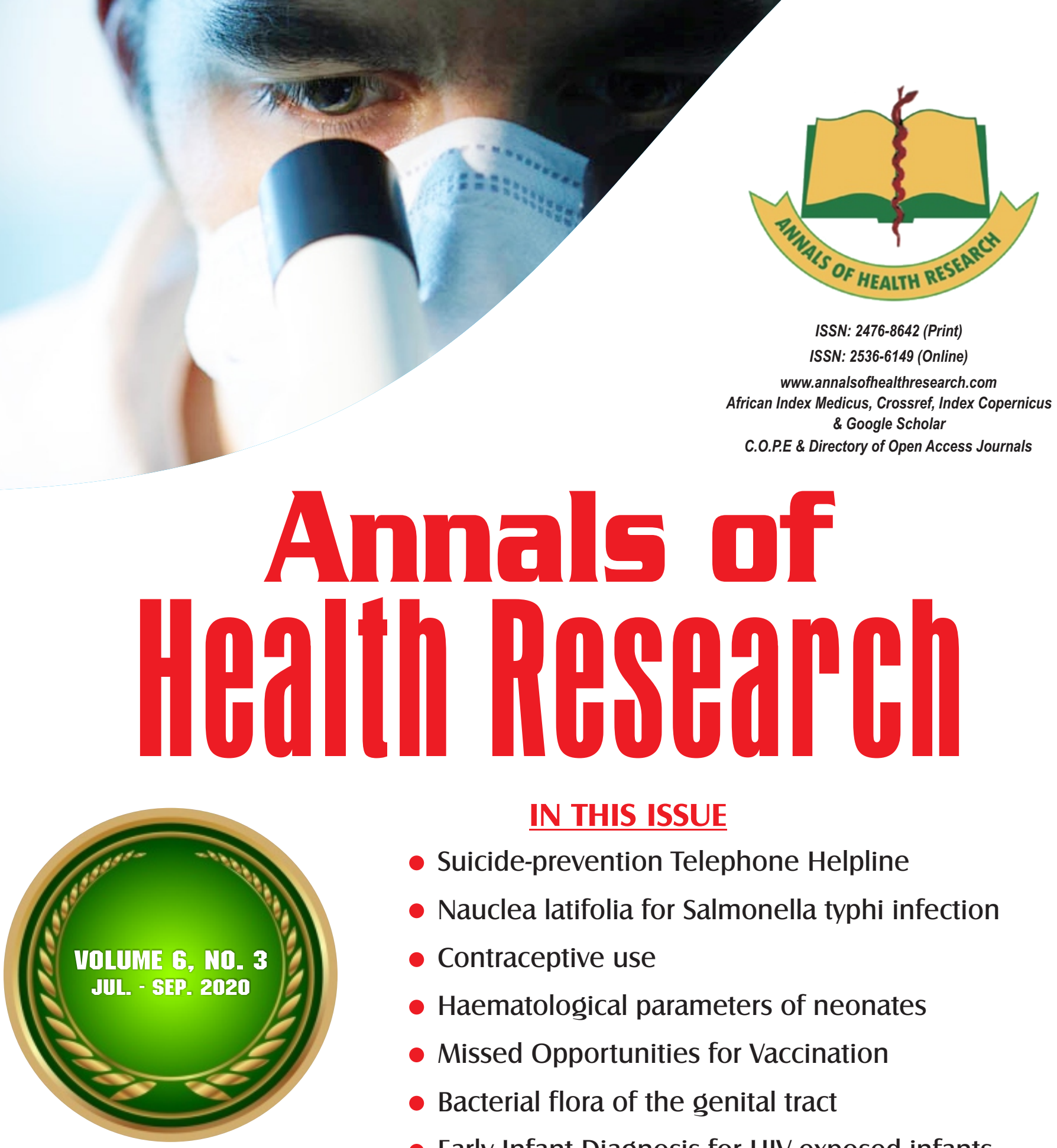

IN THIS ISSUE

- Suicide-prevention Telephone Helpline

- Nauclea latifolia for Salmonella typhi infection

- Contraceptive use

- Haematological parameters of neonates

- Missed Opportunities for Vaccination

- Bacterial flora of the genital tract

- Early Infant Diagnosis for HIV-exposed infants

- Bone markers and cardiovascular risk factors

- Attitude to termination of pregnancies

- Herpes zoster ophthalmicus

- Neonatal hyperinsulinaemic hypoglycaemia

- Paediatric perineal injury

PUBLISHED BY THE MEDICAL

AND DENTAL CONSULTANTS ASSOCIATION

OF NIGERIA, OOUTH, SAGAMU, NIGERIA.

www.mdcan.oouth.org.ng 


\title{
Haematological parameters of apparently healthy neonates at the Federal Medical Centre Bida, North Central Nigeria Ojewole OE*1, Abubakar U1, Olowu $\mathrm{AO}^{2}$ \\ Department of Paediatrics, Federal Medical Centre, Bida, Niger State, Nigeria Department of Paediatrics, Olabisi Onabanjo University Teaching Hospital, Sagamu, Ogun State, Nigeria
}

${ }^{*}$ Correspondence: Dr OE Ojewole, Department of Paediatrics, Federal Medical Centre, Bida, Niger State, Nigeria. E-mail: gokeojewole@yahoo.com; ORCID - https://orcid.org/0000-0002-4608-6423.

\begin{abstract}
Background: Haematological parameters are used as screening tools for patient's care and treatment. Objective: To determine the haematological parameters of apparently healthy term Nigerian babies and generate normative data.

Methods: This was a descriptive, longitudinal study of consecutively recruited babies. The haematological parameters were determined using venous blood samples drawn at delivery and on the $14^{\text {th }}$ day of life using a haematology auto-analyser.

Results: Of the 309 babies recruited on the first day of life, $160(51.8 \%)$ were males while $149(48.2 \%)$ were females. Two hundred and seventy-nine $(90.3 \%)$ were delivered vaginally. Most $(75 \%)$ of the neonates were of Nupe origin. The mean haematocrit, haemoglobin concentration, Mean Corpuscular Volume (MCV), Mean Corpuscular Haemoglobin (MCH), Mean Corpuscular Haemoglobin Concentration (MCHC), Red Blood Cell and reticulocyte count on Day 1 were $48.8 \pm 8.0 \%, 15.0 \pm 2.6 \mathrm{~g} / \mathrm{dl}, 104.1 \pm 8.8 \mathrm{fl}, 31.9 \pm 3.3 \mathrm{pg}, 30.7 \pm 1.7 \mathrm{~g} / \mathrm{dl}, 4.7 \pm 0.9\left(\times 10^{9} / 1\right)$ and $2.0 \pm 1.4 \%$ respectively. Corresponding Day 14 values were $41.2 \pm 5.2 \%, 12.8 \pm 1.9 \mathrm{~g} / \mathrm{dl}, 97.2 \pm 9.8 \mathrm{fl}, 30.3 \pm 3.8 \mathrm{pg}$, $31.1 \pm 1.7 \mathrm{~g} / \mathrm{dl}, 4.5 \pm 0.6\left(\times 10^{9} / 1\right)$ and $1.0 \pm 0.7 \%$ respectively. The mean White Blood Cell $(\mathrm{WBC})$ and platelet counts were $13.3 \pm 4.8\left(\times 10^{9} / 1\right)$ and $228.3 \pm 81.2\left(\times 10^{9} / 1\right)$ respectively, on the $1^{\text {st }}$ day of life and $10.1 \pm 2.4\left(\times 10^{9} / 1\right)$ and $370.1 \pm 120.7\left(\times 10^{9} / 1\right)$ respectively on the $14^{\text {th }}$ day. The mean differential WBC counts were $49.4 \pm 12.0 \%$ for neutrophils and $37.4 \pm 11.3 \%$ for lymphocytes on the $1^{\text {st }}$ day and $32.4 \pm 10.0 \%$ and $52.8 \pm 9.3 \%$ respectively on the $14^{\text {th }}$ day.

Conclusion: Neonates from Bida have haematological parameters comparable with previously reported values from other parts of Nigeria.
\end{abstract}

Keywords: Bida, Haematological parameters, Healthy, Neonates, Nigeria, Packed Cell Volume.

\section{Introduction}

Haematological parameters, including haemoglobin concentration $(\mathrm{Hb})$, haematocrit (Hct) [or Packed Cell Volume (PCV)], haematological indices [mean corpuscular haemoglobin $(\mathrm{MCH})$, mean corpuscular haemoglobin concentration (MCHC), mean corpuscular volume (MCV)], red cell count, total white blood cell count, white cell differential counts (neutrophils, lymphocytes, monocytes, basophils and eosinophils counts) and platelet count, are used in the diagnosis and monitoring of diseases. [1] The reference values of the parameters range from that derived from the normal population to those obtained in a disease state. The importance of having a reference range for haematological indices is the need for the interpretation of the 
values obtained during laboratory evaluation. Furthermore, the haematological parameters are influenced by factors such as age, [2] gender, ${ }^{[3]}$ mode of delivery, ${ }^{[4]}$ geographical location, [5] race and ethnicity. ${ }^{5]}$ It has been documented that haematological parameters are age-specific ${ }^{[6]}$ and since children are constantly growing and developing, single reference values may not be appropriate for children of all ages and in all areas.

Until recently, many developing countries, including African nations, based their reference values on those obtained from the Caucasian populations in advanced countries of the world. ${ }^{[7,8]}$ However, researchers have suggested the need for each population group to have reference values of haematological profiles derived from her population because of variations across population groups in different geographical areas. $[6,9,10]$

Despite quite a handful of Nigerian studies on haematological parameters among full-term newborns, ${ }^{[2,3,11-15]}$ most were carried out using manual methods; only a few studies $[12,13]$ were conducted in northern Nigeria more than three decades ago. Furthermore, while few studies attempted to generate reference values, the standard protocols published by the International Council for Standardisation in Haematology (ICSH) ${ }^{[16]}$ were not followed, rather mean, standard deviation and range were reported. One of these was not specific for certain days but included neonates irrespective of age. [2] In addition, the sample sizes of most of the studies were small $(<120$ recommended by the ICSH), without a focus on any major ethnic group. This study was designed to determine the values of haematological parameters among healthy term newborns delivered at the Federal Medical Centre (FMC) Bida and to derive normative data for the newborn infants of Nupe mothers, being the predominant ethnic group with a sufficient number of subjects.

\section{Methods}

This was a descriptive longitudinal study carried out at the Federal Medical Centre (FMC) Bida, between September 2015 and October 2016. The centre receives referrals from the suburbs of Abuja, Kogi, Kwara and environs. The blood samples for the study were collected from babies in the labour ward (first day of life) and the reception area of the neonatal unit of the hospital (14 $4^{\text {th }}$ day of life). Subjects that met the inclusion criteria which are highlighted below and whose mothers gave informed consent for the participation of their babies were recruited consecutively until the calculated sample size of 309 children was attained.

\section{Sample Size Determination}

According to the 2006 national population census, 36,031 of Bida population were aged 04 years. Thus, the study population was greater than ten thousand. The sample size, n, was determined using the Kish and Leslie formula for a single population,

$\mathrm{n}=\quad\left(\mathrm{z}^{2} \times \mathrm{p} \times \mathrm{q}\right) / \mathrm{d}^{2}$

Where $\mathrm{z}=$ percentile of the standard normal distribution determined by the specified confidence level, which is 1.96 for a confidence level of $95 \%$

$\mathrm{p}=$ population in the target population estimated to have a particular characteristic (using assumed proportion of 0.5 )

$\mathrm{q}=1.0-\mathrm{p}$

$\mathrm{d}=$ degree of accuracy required, usually set at 0.05

$\mathrm{n}=1.96^{2} \times 0.5 \times(1.0-0.5) /(0.05)^{2}=385$

The calculated sample size of 385 is for a population greater than 10,000 hence the sample size was adjusted to 309 .

The recruited subjects were singleton full-term normal weight $(2.5-3.9 \mathrm{~kg})$ babies from nonanaemic mothers $(\mathrm{Hb} \geq 10 \mathrm{~g} / \mathrm{dL})$ aged between 15- 45 years. The gestational age was calculated if the last normal menstrual period (LMP) was known using Naegele's rule. 
Ultrasound method was used in conjunction with clinical measurement of symphysisfundal height when an accurate LMP was unknown. Also, the gestational age of each baby was determined by the author using the new Ballard score.

Newborns conceived via assisted reproductive technology or whose mothers had antepartum haemorrhage, abnormal partograph and emergency caesarean section were excluded. Also excluded were babies with perinatal asphyxia, dysmorphic features and gross congenital malformations or babies of mothers who abused substances or had medical diseases such as hypertension and diabetes mellitus.

A semi-structured questionnaire was used to obtain the socio-demographic characteristics, including the gestational age and gender of the baby. The socio-economic classification was done based on the occupation and highest educational attainment of their parents using Oyedeji's socioeconomic classification scheme. [17]

Haematological parameters were derived from the analysis of blood samples done at the haematology department of the FMC Bida. According to the ICSH, ${ }^{[18]}$ reference ranges were obtained from a large number $(\geq 120)$ of samples from newborns of Nupe mothers. The central $95 \%$ of data from Nupe neonates were used for the development of the reference values. [16] This was based on the World Health Organisation (WHO) guidelines which suggested the use of the central $95 \%$ of data from a normal population for development of reference values in haematology. The values at the 2.5 percentile and 97.5 percentile were taken as the lower and upper limits of reference values respectively.

\section{Collection of Blood samples from subjects}

Babies were held on the same level as their mothers after delivery. The umbilical cord was clamped approximately one minute after delivery as recommended by WHO [19] and was cut 4-6 centimetres from the base of the stump using sterile scissors. Based on the blood to anticoagulant ratio specified by the manufacturer of the sample bottle (BD Vacutainer ${ }^{\circledR}$ Chicago Medical supply, LLC.), $2 \mathrm{ml}$ of blood was carefully collected from the umbilical vein of the cord stump attached to the placenta and then dispensed into the Tripotassium Ethylene Diamine Tetra Acetic acid (K $\mathrm{K}_{3}$-EDTA) bottle. The sample was gently mixed by inverting the container at least 10 times to achieve good anticoagulation and labelled appropriately.

At the age of 14 days when the sampling was repeated, those with a history fever, pallor, poor feeding, inconsolable cry or other features of sepsis and non-physiologic neonatal jaundice were sent to the neonatal unit for proper assessment and were excluded from the analysis of the $14^{\text {th }}$ day data. The blood samples were transported to the laboratory for analysis within 30 minutes of collection. Where this was not possible, the samples were refrigerated at 4-8 degree Celsius for a period of $\leq 6$ hours and were analysed within eight hours of collection.

\section{Blood sample analysis}

The Hct, $\mathrm{Hb}$, RBC count, $\mathrm{MCH}, \mathrm{MCHC}$, total WBC count, WBC differential count and platelet count were determined using Sysmex KX-21N TM automated haematology analyser Kobe Japan following the manufacturer's instructions. [20] The reticulocyte count estimation was manually performed because the automated haematology analyser utilized for this study lacked the facility to count reticulocytes. The blood smears were done as described by Bain and Lewis [21] while the number of reticulocytes on the blood smear stained with freshly prepared methylene blue was compared to the number of RBCs and reported as percentage reticulocytes. [22]

\section{Quality Control}

The automated haematology analyser was calibrated using a standardized commercially 
prepared calibrator (Haematology calibrator ${ }^{\circledR}$ Sysmex corporation Kobe Japan, batch number 012015). The performance of the analyser was also monitored by using the manufacturer's stabilized whole blood control after every 30 auto-analysed samples. In addition, blood samples of all flagged results generated by the analyser were scrupulously checked and cross-checked manually by the scientist. The flagged result was accepted if it was within $11 \%$ of the manual count for RBC, $16 \%$ for WBC and $22 \%$ for platelets counts. ${ }^{[1]}$

Three slides were made for each reticulocyte count performed. The final calculated reticulocyte percentage (an average of 2 slide counts) was accepted if the first two slides agreed within $15 \%$ of each other. If this criterion was not met, the third slide was counted and an average of the 3 slide counts was the reticulocyte percentage. [1]

\section{Ethical consideration}

Approval of the Ethical and Scientific Committee, Federal Medical Centre, Bida, was obtained before the commencement of the study. Written informed consent was obtained from the mothers of the recruited babies before enrolment into the study. All the mothers of subjects that returned on the $14^{\text {th }}$ day for follow-up were given copies of their babies' Day 1 FBC results and counselled based on the results. Babies with abnormalities in their result were given a referral to Paediatrician.

\section{Data management and analysis}

The data obtained were entered and analysed using the Statistical Package for the Social Sciences (SPSS) version 20.0. Armonk, New York. Continuous variables were summarised using descriptive methods such as mean, standard deviation and percentiles. A $p$-value of $<0.05$ was considered significant.

\section{Results}

Three hundred and nine apparently healthy singleton term newborn babies were recruited.
There were 160 (51.8\%) males and 149 (48.2\%) females with a male to female ratio of 1.1:1. Out of the 309 babies initially recruited into the study, 292 (94.5\%) babies returned for follow up on the $14^{\text {th }}$ day of life.

Of the 292 babies brought for the second phase of the study on the $14^{\text {th }}$ day, 50 were excluded because the mothers of 11 declined further participation, 15 had features of sepsis, 13 had jaundice and 11 had anaemia. Out of the remaining 242 babies that met the inclusion criteria on day 14, there were 124 (51.2\%) males and $118(48.8 \%)$ females with a male to female ratio of 1.1:1. The mean birth weights were $3.2 \pm 0.4 \mathrm{~kg}(3.2 \pm 0.4 \mathrm{~kg}$ for males and $3.1 \pm$ $0.3 \mathrm{~kg}$ for females). The predominant mode of delivery was spontaneous vertex delivery. Two hundred and ten babies on Day 1 and 169 babies on Day 14 were newborns of Nupe origin delivered by SVD.

\section{Haematological parameters of newborns \\ Red cell parameters on the first day of life}

Table I shows the overall means and malefemale differences of red cell parameters among the newborns in the study. The mean red cell parameters were comparable between males and females.

Red cell parameters on the fourteenth day of life There were no significant differences in the mean values of red cell indices of males and females as shown in Table I.

White cell and platelet counts on Day One

The overall mean values and differences by gender are shown in Table II. The mean total WBC and neutrophils counts were significantly higher among females $(p=0.006$ for WBC and $p=0.025$ for neutrophils) while the lymphocytes and platelets count were significantly lower and higher, respectively, among females $(p=0.009$ and $p=0.042$ respectively).

\section{White cell and platelet counts on Day Fourteen}

The mean values of white cell indices and platelet counts were comparable for males and females as shown in Table II. 
Table I: Haematological parameters of the newborns on Days 1 and 14 of life according to gender

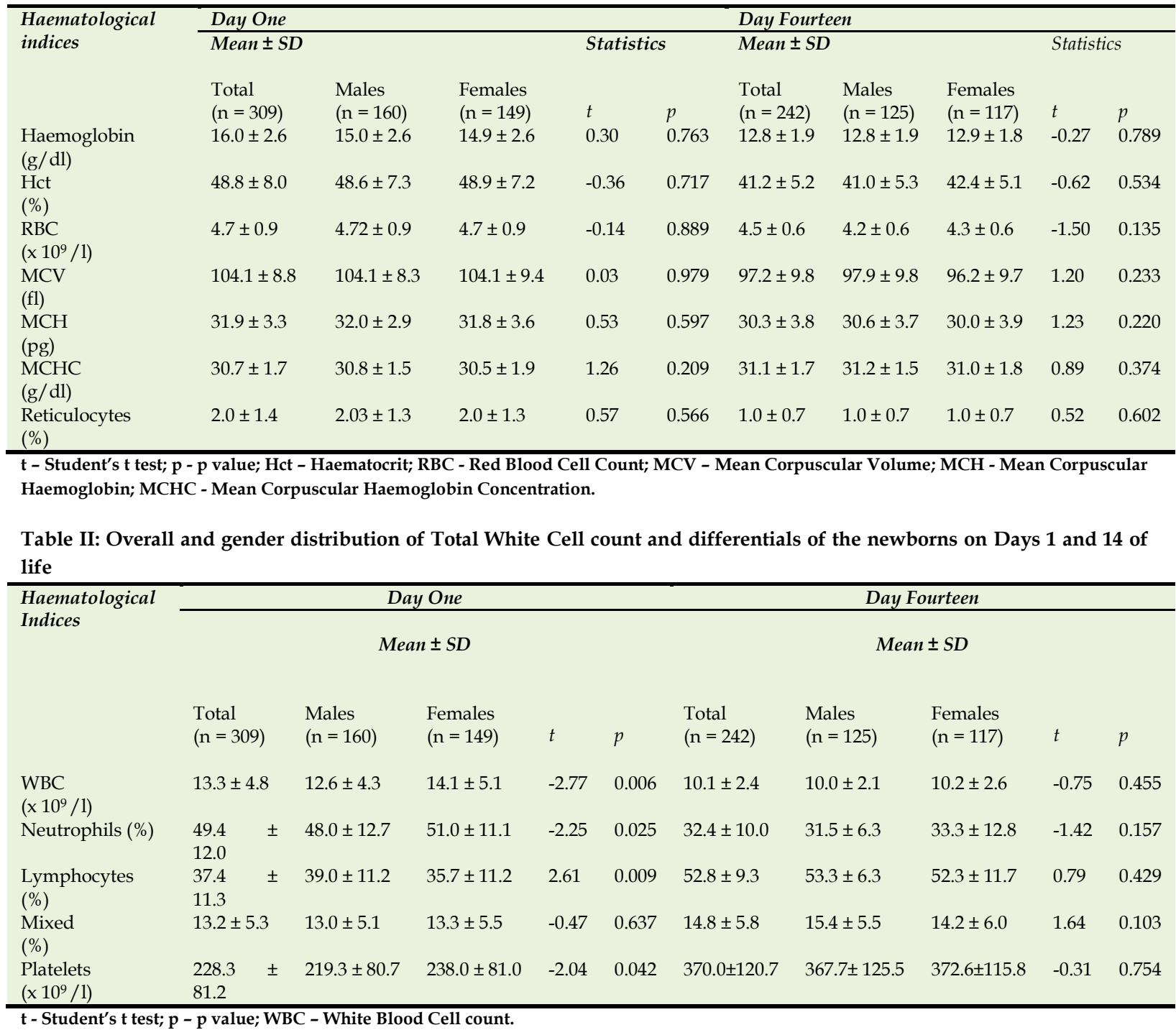

Comparison of red cell parameters on Day 1 and Day 14

Figure 1 showed that all the red cell parameters on Day 14 were significantly lower compared with the values for Day 1.

Comparison of white cell and platelet count on Day 1 and Day 14

The white cell parameters on Day 14 were significantly lower compared with the Day 1 profile except for the lymphocytes, $(p=0.001)$ (Figure 2). The platelets counts were also higher on Day 14 compared with Day 1 ( $p=$ 0.001).
Reference intervals for newborns of Nupe origin delivered via SVD

Day One

On Day 1, the reference intervals for red cell indices $(\mathrm{n}=210)$ were $\mathrm{Hb}(10.4-20.8 \mathrm{~g} / \mathrm{dl})$, PCV (34.4 - 66.1\%), RBC count (3.2 - $6.9 \times$ $\left.10^{9} / 1\right), \mathrm{MCV}$ (85.2 - 122.8fl), MCH (24.8 36.8pg), MCHC (27.6 - 33.3g/dl), and reticulocytes count $(0.2-5.1 \%)$ as shown in Figure 3 . The ranges of WBC parameters were WBC (6.6- $\left.23.2 \times 10^{9} / \mathrm{L}\right)$, neutrophils (18.4 $70.5 \%)$, lymphocytes (18.1 - 63.8\%) and mixed count $(2.4-26.4 \%)$. The platelet count ranged from $50.3 \times 10^{9} / 1$ to $371.1 \times 10^{9} / 1$ ) as depicted in

Figure

4. 


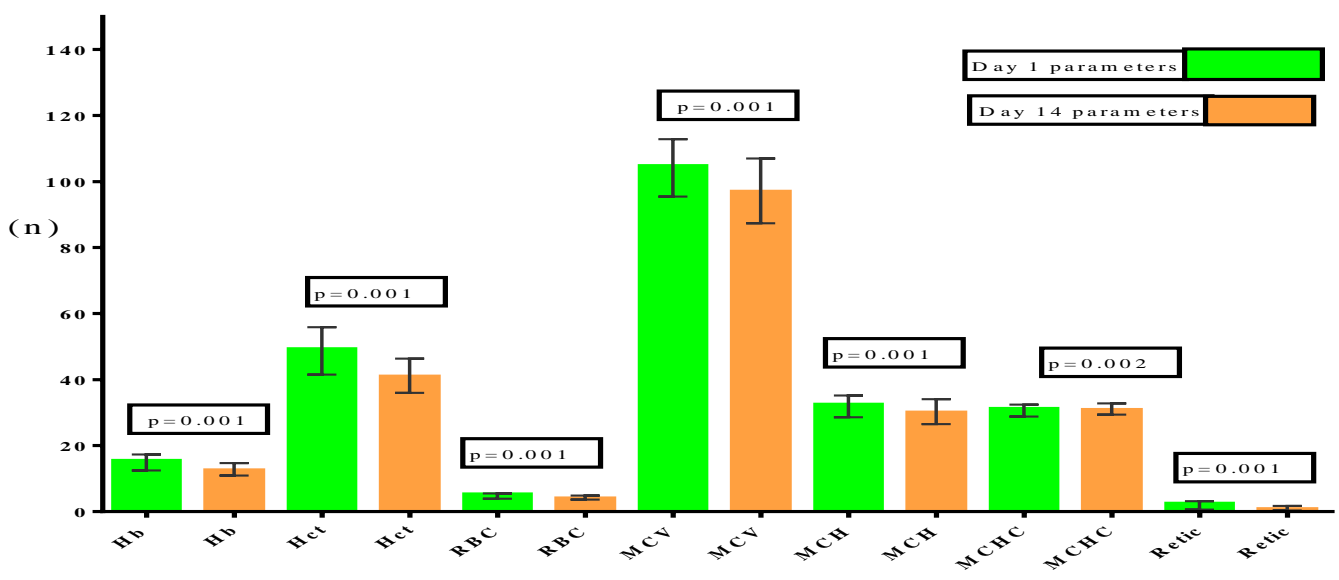

Figure 1: Comparison of red cell parameters on Day 1 and Day 14

Hb- Haemoglobin (g/dl), Hct- Haematocrit (\%), RBC- Red blood cell (x 10 /l), MCV- Mean Corpuscular Volume (fl), MCHMean Corpuscular Haemoglobin (pg), MCHC- Mean Corpuscular Haemoglobin Concentration (g/dl), Retic- Reticulocytes $(\%), \mathrm{n}$ - value of the parameters, $p$ - significance on paired $t$-test of 242 newborns.

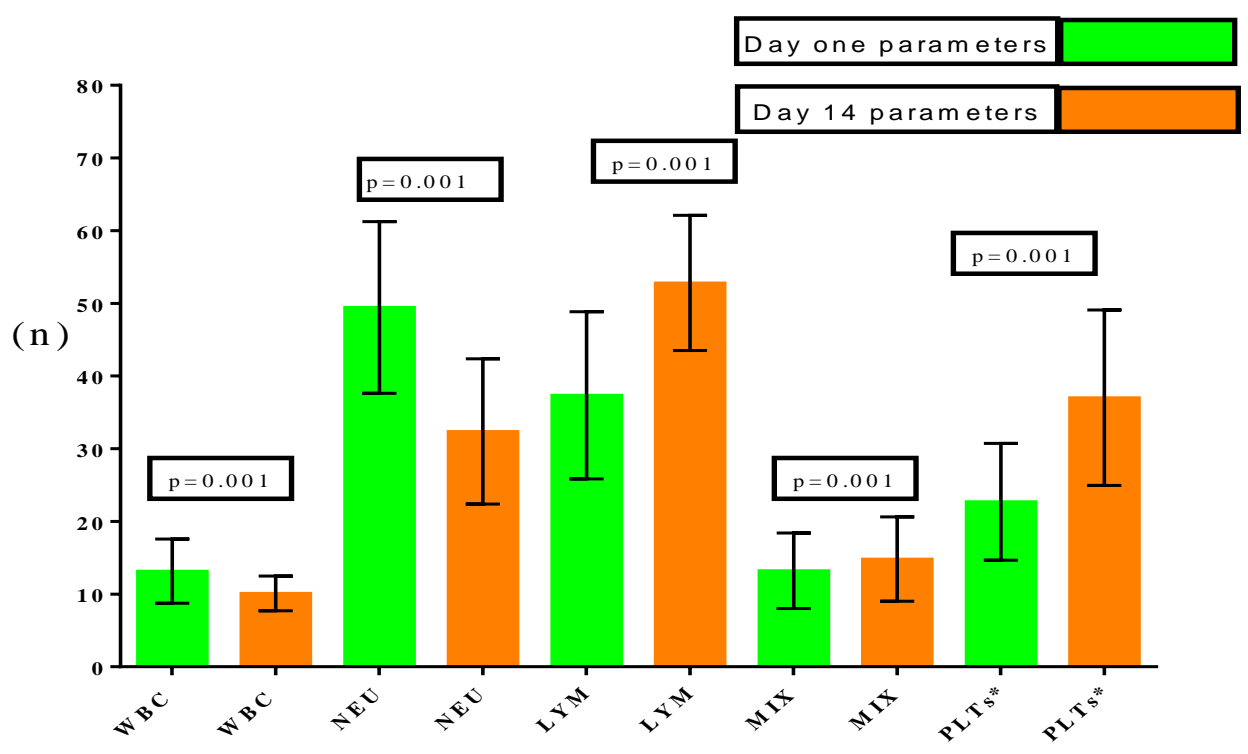

Figure 2: Comparison of White cell and Platelet counts on Days 1 and 14.

*Multiply by 10, WBC- White blood cell count (x 10\%/l), NEU- Neutrophils (\%), LYM-Lymphocytes (\%), MIX- Mixed (\%), PLTs- Platelets $\left(\times 10^{9} / 1\right)$, $n$ - value of the parameters, $p$ - significance on paired $t$-test of 242 newborns.

\section{Day Fourteen}

On Day 14, the reference ranges of red cell indices $(\mathrm{n}=169)$ were $\mathrm{Hb}(11.1-20.8 \mathrm{~g} / \mathrm{dl})$, PCV $(37.8-65.3 \%)$, RBC count $(3.4-6.3 \mathrm{X}$ $\left.10^{9} / 1\right), \quad \mathrm{MCV}(85.4$ - 123.3fl), $\mathrm{MCH}(24.8-$ $37.9 \mathrm{pg}), \quad \mathrm{MCHC} \quad(27.6-33.0 \mathrm{~g} / \mathrm{dl})$ and reticulocytes count $(0.2-5.1 \%)$ as shown in
Figure 5. The ranges for WBC parameters were WBC (6.6 - $\left.15.3 \times 10^{9} / 1\right)$, Neutrophils (20.9 $68.8 \%)$, Lymphocytes (17.6 - 64.5\%), mixed count $(2.6-26.4 \%)$ while the range for platelet count was $51.5 \times 10^{9} / 1$ to $371.3 \times 10^{9} / 1$ ). Further details are shown in Figure 6. 


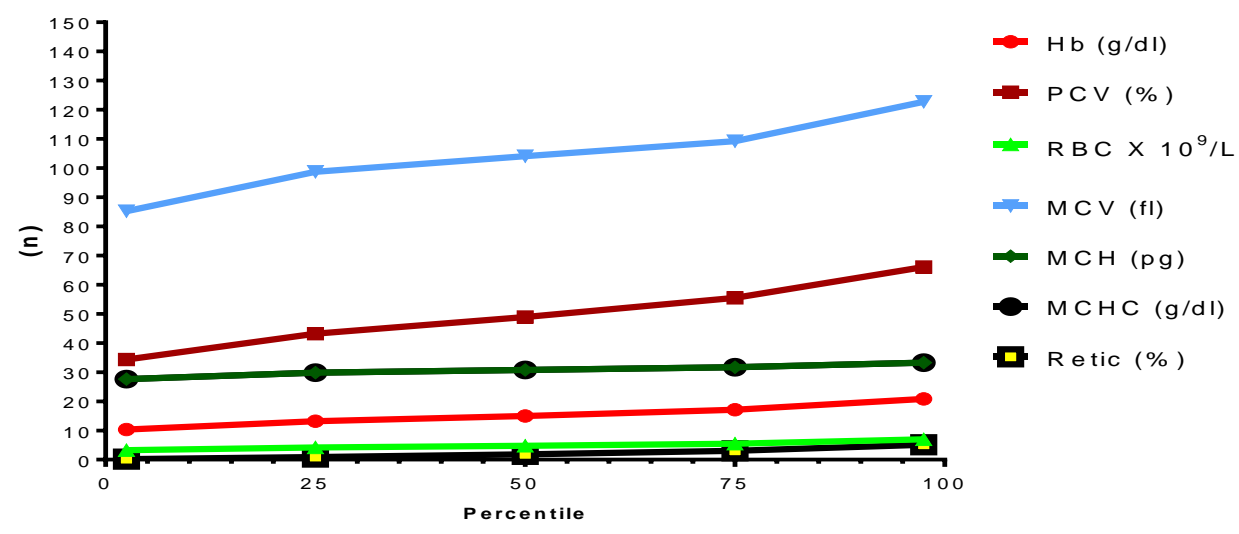

Figure 3: Reference intervals of red cell indices on Day 1 of life NB: $n$ - value of the parameters

\section{Discussion}

The mean values of all the haematological parameters in the current study are generally lower than those reported among children living in developed countries. ${ }^{[23,24]}$ This may be attributed to the difference in genetic makeup, the high prevalence of maternal anaemia and nutritional peculiarities in this sub-region. [18,25]

The mean cord $\mathrm{Hb}$ in the present study is similar to the values documented in previous local reports [13,15] but higher than others. [3,12,14] However, it is lower than that of Caucasians [23,24] and Malawians. [26] Babay et al. [27] and Karazawa et al. [28] have established the influence of the environment, especially altitude, on haemoglobin concentration $(\mathrm{Hb})$. Bida and its environs are about 153 metres above sea level. This could explain the lower mean $\mathrm{Hb}$ compared to the mean of $16 \mathrm{~g} / \mathrm{dl}$ for the high altitude area of Malawi,[26] which is about 766 metres above sea level. The effect of hypobaric hypoxia at high altitude is known to stimulate erythropoiesis. [28,29] The mean cord RBC count is similar to those reported by other authors [13,14] but lower compared to that reported by Ogundeyi et al. [15] among newborn babies in south-western Nigeria. The value of similar parameter reported from
Pakistan, ${ }^{[6]}$ another developing country, was far lower than the mean value recorded in the present study. The present study also reports a higher mean value of MCV in the umbilical cord blood than the reports of Dapper et al. [14] and Ogundeyi et al. ${ }^{[15]}$

Comparison of reticulocyte count shows the mean cord blood value of $2.0 \%$ in the present study is lower than $3.5 \%$ reported by Ogundeyi et al. [15] and 4.4\% reported from northern Nigerian by Abdurrahman and Adekoje. [30] These authors [15,30] also utilized the manual method of reticulocyte estimation. The observed differences might, therefore, be operator-dependent (visual acuity and patience of the observer) or due to differences in the resolution of the microscopes used. [31] The mean cord Hct or PCV in the present study is higher than the corresponding values reported from Sagamu [15] and northern Nigerian, ${ }^{[12]}$ hence it is not surprising that the mean reticulocytes count is lower.

The mean cord WBC in the present study is comparable to the values previously recorded among Pakistani ${ }^{[6]}$ and Malawian ${ }^{[26]}$ neonates but higher than those reported from Sagamu, ${ }^{[15]}$ Port Harcourt, [14] and Zaria. [13] The mean cord neutrophils value of $49.4 \%$ is 
similar to the value reported by Danish et al. [6] from Pakistan but different from the finding in Sagamu, Nigeria [15] in which there was a higher value of $56.8 \%$ in blood samples drawn at birth. Also, the mean lymphocytes count on Day 1 is similar to that obtained from neonates in south-west Nigeria but lower than that reported from Pakistanis. [6] However, the value reported from Zaria [13] was lower. These studies, [6,15] were done using automated haematology analysers after strict recruitment procedure. [15] However, the blood samples used in the Sagamu study were drawn from peripheral vein 2-6 hours after delivery. [15]

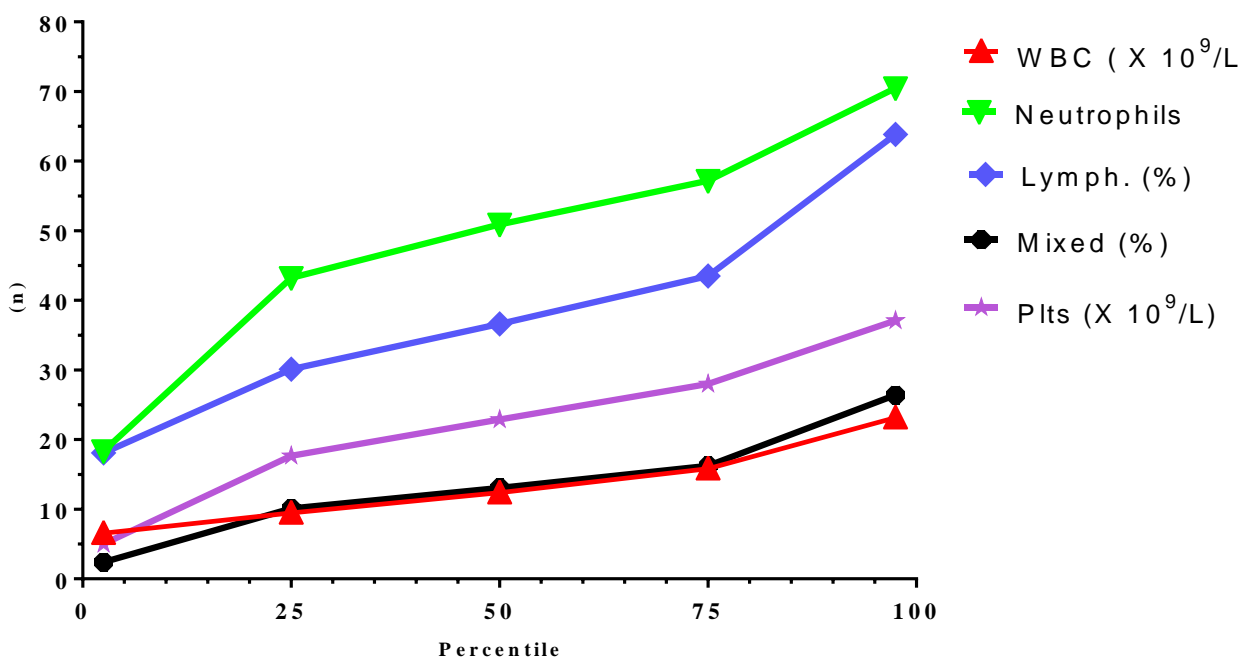

Figure 4: Reference intervals of white red cell indices and platelet counts on Day 1 of life. NB: Multiply Platelet (Plts) count by 10; Lymph-lymphocytes, $n$ - value of the parameters

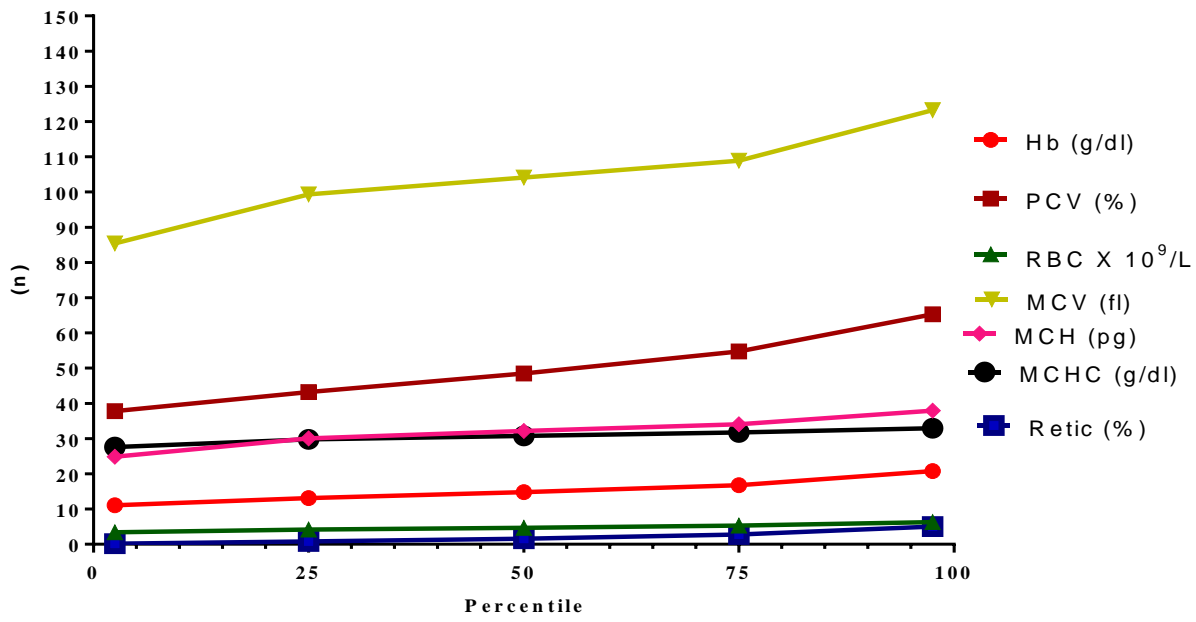

Figure 5: Reference intervals of red cell indices on Day 14 of life. NB: $n$ - value of the parameters 


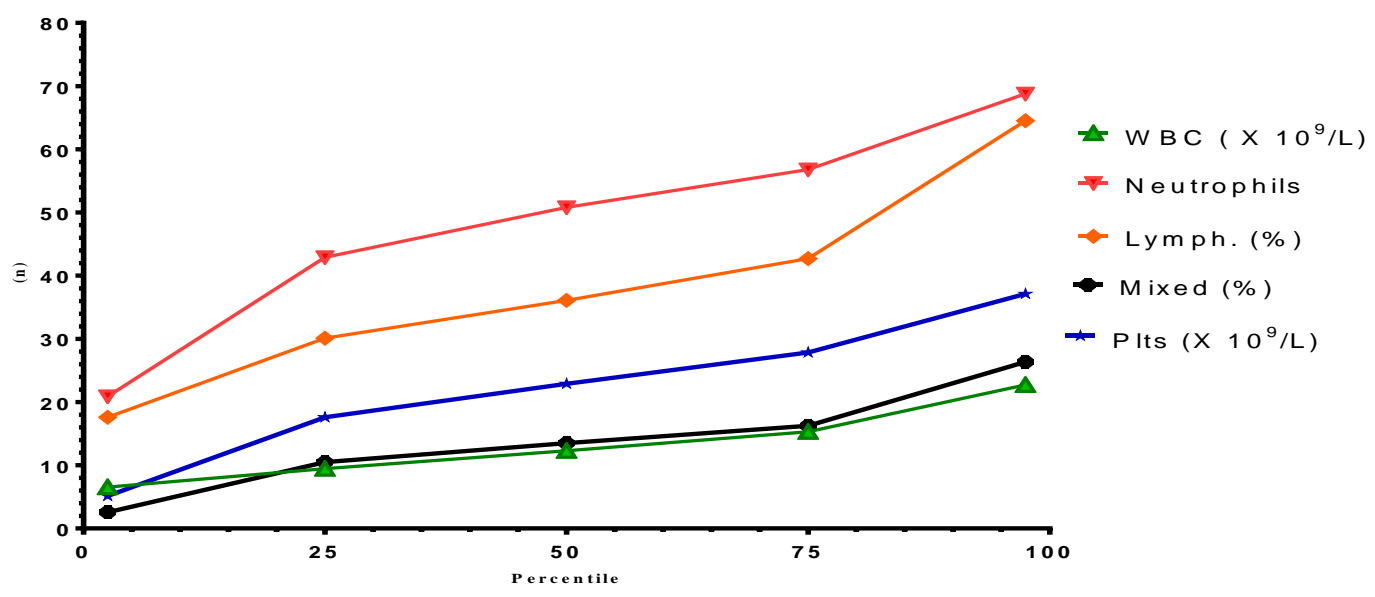

Figure 6: Reference intervals of white cell indices and platelet count on Day 14 of life. NB: Multiply platelet (Plts) count by 10; Lymph- lymphocytes, n- value of the parameters

The mean cord platelet count in the present study is higher than $173 \times 10^{9} / 1$ reported from northern Nigeria, ${ }^{[12]}$ but lower than the recent value of $261 \times 10^{9} / 1$ from South-west Nigeria. [15] Other authors have equally reported higher platelet counts. $[6,26]$

The mean values of red cell parameters on Day 14 were generally lower than the values reported from advanced countries except for RBC and reticulocyte counts which were higher. [23] The observed mean values for $\mathrm{Hct} / \mathrm{PCV}$ and $\mathrm{Hb}$ fell in the range given by Ogala and Wammanda [32] but are lower than the values reported among Caucasian children. [23] The variations may be due to racial, dietary and environmental influences. [23,25]

The mean $W B C$ on the $14^{\text {th }}$ day of life is comparable to the values cited by Ogala and Wammanda. [32] Also, the observed lymphocytes predominance is in agreement with previous reports from among African and Caucasians newborns. ${ }^{[15,32,33]}$ The research by Reich et al. [34] involving African and European Americans showed that a dominant European-derived allele contributed to high neutrophil count among European Americans. Therefore, the effect of the genetic contribution to WBC count has been further substantiated. The mean percentage lymphocytes count on
Day $14(52.80 \%)$ was lower than the 65.87\% reported by Ogala and Wammanda. [32] On the contrary, the mean percentage neutrophils count was higher. ${ }^{[32]}$ The predominance of lymphocytes after one week of life is in keeping with earlier reports. [23,24,32]

The mean platelet count for the $14^{\text {th }}$ day of life in the present study is higher than the mean value cited in the standard textbook for African children. ${ }^{[32]}$ The difference may have to do with variations in methodology. [35]

\section{Conclusion}

The reference values obtained in this study can be adopted as local reference standards for clinical diagnosis, evaluation and monitoring of term neonates in the local setting.

Acknowledgement: The authors appreciate Dr Ibrahim OR of the Department of Paediatrics, Federal Medical Centre, Kastina, for his contributions during this work.

Authors' Contributions: OOE conceived and designed the study and did data acquisition. AU and OAO participated in the design of the study. OOE, AU and OAO performed data analysis and interpretation. OOE drafted the manuscript and AU and OAO reviewed the draft. All the authors approved the final version of the manuscript.

Conflict of interest: None declared. 
Funding: Self-funded.

Publication History: Submitted 26 February 2020; Accepted 30 June 2020.

\section{References}

1. Perkins SL. Examination of the Blood and Bone Marrow. In: Wintrobe M, Lee G (eds). Wintrobe's Clinical Haematology. Williams and Wilkins Co: Baltimore, 2006: 27-74.

2. Buseri F, Siaminabo I, Jeremiah Z. Reference values of hematological indices of infants, children, and adolescents in Port. Pathol Lab Med Int 2010; 2: 65-70.

3. Adediran A, Adeyemo TA, Akinbami A, Gbadegesin A, Ebele U, Akanmu S. Cord blood full blood count parameters in Lagos, Nigeria. Pan Afr Med J 2014; 17: 192.

4. Danish H, Mohammad P, Tahseen K, Syed $\mathrm{T}$. Influence of maternal factors on haematological parameters of healthy newborns of Karachi. Par J Physiol 2009; 5: 34-37.

5. Waseem P, Waqar A, Abdullatif K, Nayyer A, Muhammad I, Z ameer AN. Reference haematological values for full-term healthy newborns from rural Sindh, Pakistan. J Ayub Med Coll Abbottabad 2015; 27: 375-377.

6. Danish QH, Mohammad SP, Syed AT, Tahseen K. Haematological reference values for full-term, healthy, newborns of Karachi, Pakistan. J Pak Med Assoc 2009; 59: 618-622.

7. Dosoo DK, Asante KP, Kayan K, AduGyasi D, Osei-Kwakye K, Mahama E et al. Biochemical and hematologic parameters for children in the middle belt of Ghana. Am J Trop Med Hyg 2014; 90: 767-773.

8. Usman K, Syed ZA, Rao AA. Reference range values of haematological parameters in healthy Pakistani adults. Pak J Physiol 2007; 3: 19-22.
9. Basnet S, Singh SK, Sathian B, Mishra R. Reference ranges for haematological values in umbilical cord blood in Pokhara, Nepal. J Nepal Paediatr Soc 2016; 36: 263267.

10. Quintó L, Aponte JJ, Sacarlal J, Espasa M, Aide P, Mandomando I et al. Haematological and biochemical indices in young African children: in search of reference intervals. Trop Med Int Health 2006; 11: 1741-1748.

11. Effiong C, Taiwo O, Odeniyi O, Mellits E. Haematological values in healthy full-term Nigerian newborn infants. Bio Neonate 1976; 28: 336-346.

12. Abdurrahman MB, Adekoje MA. Haematological values in northern Nigerian neonates. Trans R Soc Trop Med Hyg 1983; 77: 786-788.

13. Ogala WN. Haematological values in healthy Nigerian infants. Ann Trop Paediatr 1986; 6: 63-66.

14. Dapper D, Didia B. Haematological parameters of umbilical cord blood of Nigerian newborns: Correlation with maternal parameters. W Afr J Med 2006; 25: $226-230$.

15. Ogundeyi M, Olarewaju D, Njokanma O, Ogunlesi T. Haematological profile of apparently healthy term babies aged one day, three days and six weeks delivered in Sagamu, Nigeria. Niger J Paediatr 2011; 38: 125-130.

16. Lewis S. Statistical procedures. In: Lewis $S$ (Ed). World Health Organization quality assurance in Haematology. WHO: Switzerland, 1998: 19-42.

17. Oyedeji G. Socio-economic and cultural background of hospitalised children in Ilesha. Niger J Paediatr 1985; 12: 111-117.

18. Imelda $B$, Lewis $S M$. Reference ranges and normal values. In: Barbara JB, Imelda B, Michael AL, Lewis SM (eds). Dacie and Lewis Practical Haematology. Churchill Livingstone: China, 2011: 10-22. 
19. WHO. Guideline: Delayed umbilical cord clamping for improved maternal and infant health and nutritional outcomes. Geneva, 2014.

20. Corporation S. Operator's manual Automated Haematology analyser KX-21. 2000.

21. Bain B, Seed M. Platelet count and platelet size in healthy Africans and West Indians. Clin Lab Haematol 1986; 8: 43-48.

22. Briggs $\mathrm{C}$, Bain BJ. Basic haematological techniques. In: Barbara JB, Imelda B, Michael AL, Lewis SM (Eds). Practical Haematology. Elsevier Churchill Living stone: China, 2011: 23-56.

23. Luchtman-Jones L, Schwartz AL. Haematological problems in the fetus and neonate. In: Fanaroff and Martin's Neonatal-Perinatal Medicine. Elsevier's Health sciences rights department: Philadelphia, 2006.

24. Barbara J, Robert M. Blood disorders. In: Kleigman R, Behrman R, Jenson H, Stanton B (Eds). Nelson textbook of paediatrics. WB Saunders Company: Philadelphia, 1996: 599-601.

25. WHO. The global prevalence of anaemia in 2011. Switzerland, Geneva, 2011.

26. Mukiibi JM, Mtimavalve L, Mzula E, Dzinyemba WEW, Merrick R, Mtimavalye LA et al. Some haematological parameters in Malawian neonates. East Afr Med J 1995; 72: 10-14.

27. Babay ZA, Addar MH, Warsy AS, ElHazmi MA. The inter-relationship hematological parameters between Saudi newborns and parents. Saudi Med J 2002; 23: 943-946.
28. Karazawa EH, Jamra M. Normal hematologic parameters. Rev Saude Publica 1989; 23: 58-66.

29. Shrivastava A, Goyal A, Negi K. Effect of high altitude on haematological parameters. Indian J Prev Soc Med 2010; 41: 41-46.

30. Abdurrahman MB, Adekoje MA. Haematological values in northern Nigerian neonates. Trans R Soc Trop Med Hyg 1983; 77: 786-788.

31. Jaebum C, Xiaoze O, Rajan PK, Changhuei Y. Counting white blood cells from a blood smear using Fourier ptychographic microscopy. PLoS One 2015; 10: 1-6.

32. Ogala W, Wammanda R. Physiology of haematopoiesis and haemostasis. In: Azubuike J, Nkanginieme K (Eds). Paediatrics and child health in a tropical region. African educational services: Owerri, 2007: 347-351.

33. William WHJ, Levin MJ, Sondheimer JM, Deterding RR. Haematologic disease. In: William W. Hay J, Levin MJ, Sondheimer JM, Deterding RR (Eds). Current Paediatrics Diagnosis and Treatment. The McGraw-Hill Companies, Inc: USA, 2007.

34. Reich D, Nalls MA, Kao WHL, Akylbekova EL, Tandon A, Mullikin J et al. Reduced Neutrophil count in people of African descent is due to a regulatory variant in the Duffy antigen receptor for chemokines gene. PloS Genet 2009; 5: 1-14.

35. Njokanma O. Blood disorders in the newborn and early infancy. In: Azubuike J, Nkanginieme K (eds). Paediatrics and child health in a tropical region. African educational services: Owerri, 2007: 351354 . source is adequately cited and credited. 